\title{
Carbon, Nitrogen and Sulphur Pools and Fluxes in Pyrite Containing Reclaimed Soils (Technosols) at Gabra Village, Bulgaria
}

\author{
Venera Tsolova $\cdot$ Viktor Kolchakov $・$ Miglena Zhiyanski
}

Received: 18 May 2014 / Accepted: 19 August 2014 / Published online: 7 September 2014

(C) Springer International Publishing Switzerland 2014

\begin{abstract}
The present paper deals with the characteristics of $\mathrm{C}, \mathrm{N}$ and $\mathrm{S}$ pools and fluxes in pyrite containing Technosols located in the area of Chukurovo mine (Gabra village, Bulgaria) in a view of nutrient geochemical transformations in a specific technogenic environment. The role of vegetation and soil microbiota for stabilization of nutrient pools and fluxes has also been taken into consideration. Chemical and microbiological assays are used to analyze the contents and transformation rates of $\mathrm{C}$, $\mathrm{N}$ and $\mathrm{S}$. Determination of $\mathrm{C}: \mathrm{N}$ and $\mathrm{C}: \mathrm{S}$ ratios filling out the knowleadge of interactions between studied nutrients in pyrite containing environment. Cinnamon forest soils /Endogleyic Luvisols (Siltic, Chromic) are also included in the study in order to provide a basis for comparison. According to the results obtained carbon and nitrogen geochemical pools are interlinked by organic matter in Gleyic Technosols (Siltic). Soil microbiota predominantly manage nitrogen organic and inorganic fluxes and presumably are the main reason for low saturation of organic matter with nitrogen $(\mathrm{C}: \mathrm{N}=11)$. In young Technosols /Stagnic Technosols (Clayic)/prevail the pools of coal carbon and the scarce fluxes of nitrogen. The average value of $\mathrm{C}: \mathrm{N}$ is 38 but still the strong correlation between elements exists. Pyrite is the main source of sulfur providing predominance of inorganic pools and fluxes. It conceals the natural interlink beteewn carbon and sulphur organic pools resulting in very low values of $\mathrm{C}: \mathrm{S}$ (average value of 7.5). Microorganisms responsible for the oxidative turnover of inorganic sulfur compounds prevail and further sustain the acidic $\mathrm{pH}$ in young soil solum.
\end{abstract}

Keywords Technosols $\cdot$ Pyrite $\cdot$ Coal admixture $\cdot$ Soil microbiota $\cdot \mathrm{C}, \mathrm{N}$ and $\mathrm{S}$ pools and fluxes

\footnotetext{
V. Tsolova $(\bowtie) \cdot$ V. Kolchakov

N. Poushkarov Institute of Soil Science, Agrotechnologies and Plant Protection,

7 Shoose Bankya, 1080 Sofia, Bulgaria

e-mail: venera_tsolova@abv.bg
}

M. Zhiyanski

Forest Research Institute, 132 Kliment Ohridski, 1756 Sofia, Bulgaria 


\section{Introduction}

Mining industry has rapidly developed in the twentieth century in Bulgaria and caused serious negative impact on the environment. The immediate effect displays in devastation of the soil cover, the alteration of local hydrogeology and modification of the relief. The open cast mining most radically transformed the natural landscape because of the huge amount of earth materials which have been discovered, transported and utilized in mine zones. These materials are used for land creation (of the so-called spoils, dumps, mine soils or reclaimed soils) and usually cover about $60 \%$ of mine territories. Mines, furthermore, function long period of time and constantly affect new areas. Meanwhile, the dump reclamation proceeds slowly and additionally disturbs the ecological balance in mine regions of Bulgaria (MEW, ExEA 2014).

Reclaimed soils (formed during the extraction of minerals and natural materials) are located near the mining and processing plants and have specific characteristics associated with the origin, composition and properties of parent materials and their organization. Generally, the reclamation resulted in creation of soils, whose properties and productive potential significantly differ from these of the natural soils on which they are located (Ghose 2005; Wong 2003; Sheoran et al. 2008; Tsolova et al. 2012). New soils are less affected by weathering processes and many of their properties could be substantially changed after reclamation (Marinkina 1999; Sheoran et al. 2010). The most common degradation changes are associated with sulfides content and the process of sulfuricization. Sulfuricization occurs when sulfide minerals, such as pyrite $\left(\mathrm{FeS}_{2}\right)$, are oxidized, and the produced sulfuric acid accelerates the weathering of soil, and starts the formation of new mineral phases from the dissolution process (Fanning and Fanning 1989; Fanning and Burch 1997; Sencindiver and Ammons 2000). Sulfuricization may be the most important process of soil formation in acid mine soils developed in pyritic materials (McCloy and Sencindiver 1991). Acid sulfate weathering (sulfuricization) enriched soils with yellow jarosite $\left(\mathrm{KFe}_{3}\left(\mathrm{SO}_{4}\right)_{2}(\mathrm{OH})_{6}\right)$ mottles, free sulfate ions and cations such as $\mathrm{H}^{+}, \mathrm{Ca}^{2+}, \mathrm{Mg}^{2+}, \mathrm{K}^{+}$, and $\mathrm{Al}^{3+}$ (Singh et al. 1982; Ciolkosz et al. 1985; Johnson and Skousen 1995; Marinkina 1999).

Oxidation of sulfides to sulfuric acid causes the phenomenon of "acid mine drainage" through which many compounds are released in the environment (Benvenuti et al. 1997; Sheoran and Sheoran 2006; Hegler et al. 2008; Donggan et al. 2011; Thorsten 2013). Acid mine drainage is a unique pollutant because acid generation and discharges continue to occur even when mining has ceased (USEPA 1978). In such devastating environment, the interactions between soil components which determine the basic soil properties and functionality are of great interest.

This paper deals with the characteristics of $\mathrm{C}, \mathrm{N}$ and $\mathrm{S}$ pools and fluxes in pyrite containing Technosols located in the area of Chukurovo mine (Gabra village, Bulgaria)) in a view of nutrient geochemical transformations in a specific technogenic environment. The role of vegetation and soil microbiota for stabilization of nutrient pools and fluxes has also been taken into consideration.

\section{Materials and Methods}

\subsection{A Brief Description of Studied Soils}

Reclaimed soils located near "Chukurovo" mine are constructed as heterogeneous mixture of Miocene geological materials which covered the coal horizons. They are directly reclaimed (without soil amendment) with mixed black pine (Pinus nigra Arn.) and birch (Betula pendula 
Roth.) plantation - "Zapad" spoil (representative profile 1 with geographic coordinates: $42^{\circ} 33^{\prime}$ $11.81^{\prime \prime}$ N, $23^{\circ} 35^{\prime} 51.47^{\prime \prime}$ E; Figs. 1 and 2) and by pure black pine plantation -"Mlada gvardia" spoil (representative profile 2 with geographic coordinates: 42 $32^{\prime} 24.94^{\prime \prime} \mathrm{N}, 23^{\circ} 36^{\prime} 15.55^{\prime \prime} \mathrm{E}$; Figs. 1 and 3). The period of post-reclamation development of soils is 30 and 20 years, respectively.

The humus layer of cinnamon forest soil /Endogleyic Luvisols (Siltic, Chromic) with geographic coordinates: $42^{\circ} 31^{\prime} 48.45^{\prime \prime} \mathrm{N}, 23^{\circ} 37^{\prime} 27.04^{\prime \prime} \mathrm{E}$ from the village of Gabra is also included in the study in order to provide a control plot and a basis for comparison (Fig. 1).

\subsection{Methodology}

The field study was performed in accordance with the Guidance for soil description (FAO 2006). Sampling procedures were carried out by trial pit manual sampling described in ISO 10381-2 and ISO 10381-4 which are also Bulgarian State Standards (BSS) since 2005. Disturbed samples were taken from each morphologically distinguished soil horizon or layer related to each $20 \mathrm{~cm}$ depth as well. Preparation of samples for physico-chemical analysis meets the requirements of BSS ISO 11464:2012.

The following parameters were determined:

Total nitrogen content - method BSS ISO 11261:1995;

Total sulphur content-method of soil extraction with acid mixture of $\mathrm{HCl}: \mathrm{HNO}_{3}$ at ratio 3:1 and subsequent determination by BSS ISO 11048:2002;

Total carbon content-modified method of Turin (Banov et al. 2013).

The isolation, identification and enumeration of the main groups of microorganisms were carried out by conventional methods described by Karavaiko et al. (1988) and Groudeva et al. (1993).

Total bioactivity and biomass carbon were determined by gas chromatographic method (Anderson and Domsch 1978). Microbiological soil characteristics were determined in undisturbed samples from humus horizons or surface layers with $5 \mathrm{~cm}$ depth.

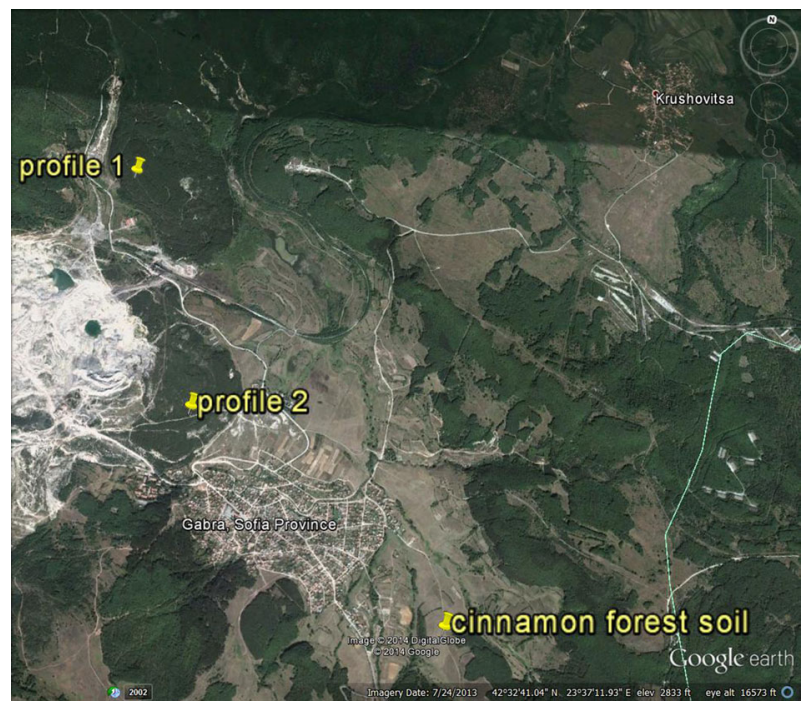

Fig. 1 Location of studied objects 


\section{Results and Discussion}

\subsection{Soil Features and Nutrient Pools}

The studied soils' taxonomy according to the World Reference Base Classification System (2006) is:

- Gleyic Technosols (Siltic)-reclaimed soils with 30 years of post-reclamation development, profile 1 (Fig. 2);

- Stagnic Technosols (Clayic) - reclaimed soils with 20 years of post-reclamation development, profile 2 (Fig. 2).

Reclaimed soils characterize with deep profiles $(>2 \mathrm{~m})$, which are partially changed by hypergenic transformations. Pedogenesis in genetically older soils /Gleyic Technosols (Siltic)/ proceeds with accumulation of organic matter, in contrast to Clay loam soils (profile 2) which are devoid of humus. The humus formed at this stage is referred to the calcium mull type (Duchaufour 1970) and termed as non-mature form - dark colored saturated humus (V>70\%), with neutral $\mathrm{pH}$, crumbly with granular structure, well humified, stable. Considering the C:N value (Table 1) it is slightly saturated with nitrogen (Orlov 1995). The low content of nitrogen in carbon organic compounds occurring in $\mathrm{C}$ horizons might be considered as their paleogenic feature which provokes chemical stability and prevents the loss of organic carbon.

Genetically younger soils /Stagnic Technosols (Clayic)/ are enriched with carbon and sulphur due to the abundance of coal admixtures and high pyrite content (Table 1). Fine coal admixtures of a size less than $2 \mathrm{~mm}$ were not removed during the analysis in order to avoid the further treatment of the samples. Some studies confirmed the negligible mineralization of coal fragments (Tsolova et al. 2011; Slattery and Surapeneni 2002; Yazawa et al. 2002) and reveal that new nutrient flux formation or changes in the soil matrix can not be expected. Coal artefacts therefore should be considered as an inert biogenic pool of carbon, nitrogen and sulphur.

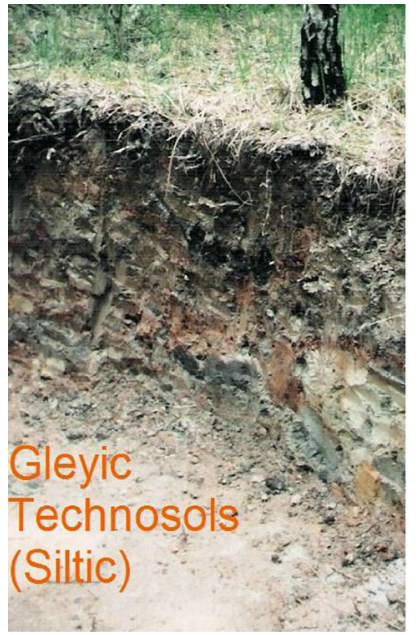

(a)

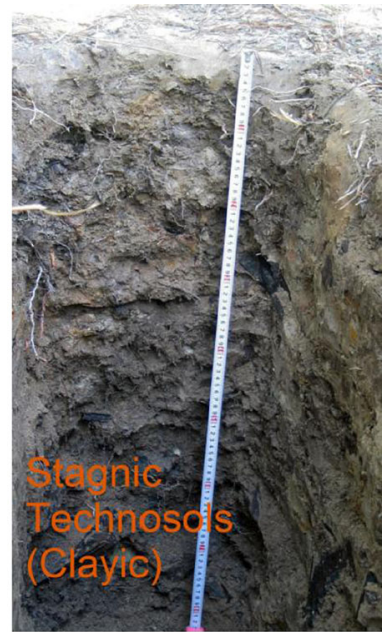

(b)

Fig. 2 Profile views of Technosols 


\section{Profile 1}

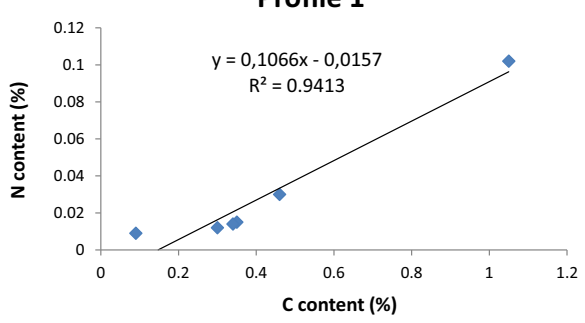

a

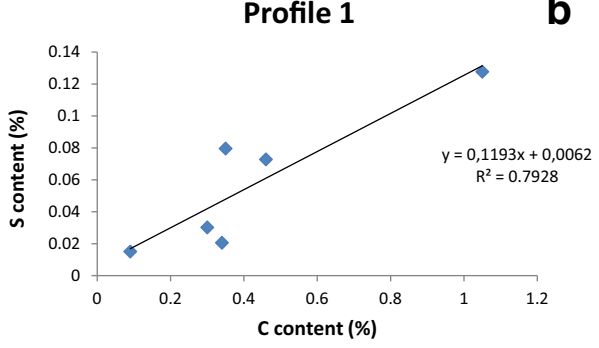

Fig. 3 Relationships between $\mathrm{C}$ and $\mathrm{N}(\mathbf{a})$ and $\mathrm{C}$ and $\mathrm{S}(\mathbf{b})$ in profile 1

Cinnamon soils /Endogleyic Luvisols (Siltic, Chromic)/ contain naturally formed humus which might be determined as eutrophic mull, a subtype of forest mull type (Duchaufour 1970) which features include high base saturation (96.44\%), acidic $\mathrm{pH}$ (5.4) and specific morphogenesis.

Presumably, the cycle of element transformations will be more intensive in genetically older soils, wherein water infiltration induces the visible morphological changes. The vegetation cover is the major factor for stabilization of nutrient cycles and predominance of organic pools of carbon, nitrogen and sulphur in these soils. The young soil solum is still slightly changed by biogeochemical processes but the aggressive chemical environment could reform their matrix. Historically, the aggressive soil environment had retarded the plant germination for 20 years (Marinkina and Banov 2001).

The correlations between $\mathrm{C}$ and $\mathrm{N}$ (Figs. $3 \mathrm{a}$ and $4 \mathrm{a}$ ) and $\mathrm{C}$ and $\mathrm{S}$ (Figs. $3 \mathrm{~b}$ and $4 \mathrm{~b}$ ) illustrate the basic pattern of nutrient cycles in studied Technosols.

Strongly interlinked (coupled) pools and cycles of nitrogen and carbon are found in both soils while the pyrite form of sulfur increases inorganic flux of $\mathrm{S}$ by increasing the content of

Table 1 Chemical properties of studied soils

\begin{tabular}{|c|c|c|c|c|c|c|c|}
\hline Horizon & Depth $(\mathrm{cm})$ & $\mathrm{pH}$ & Total C (\%) & Total N (\%) & Total S (\%) & $\mathrm{C}: \mathrm{N}$ & $\mathrm{C}: \mathrm{S}$ \\
\hline \multicolumn{8}{|c|}{ Gleyic Technosol (Siltic) - profile 1} \\
\hline $\mathrm{AC}$ & $0-5$ & 6.7 & 1.05 & 0.099 & 0.1277 & 11 & 8 \\
\hline $\mathrm{C} 1$ & $5-25$ & 7.2 & 0.46 & 0.030 & 0.0728 & 15 & 6 \\
\hline $\mathrm{C} 2$ & $25-40$ & 6.9 & 0.30 & 0.012 & 0.0302 & 25 & 10 \\
\hline $\mathrm{Cg} 1$ & $40-60$ & 7.0 & 0.35 & 0.015 & 0.0796 & 23 & 4 \\
\hline $\mathrm{Cg} 2$ & $60-80$ & 6.8 & 0.34 & 0.014 & 0.0206 & 24 & 17 \\
\hline $\mathrm{Cg} 3$ & $80-100$ & 6.5 & 0.09 & 0.009 & 0.0151 & 10 & 6 \\
\hline Average & & 6.85 & 0.43 & 0.030 & 0.0577 & 14 & 7 \\
\hline \multicolumn{8}{|c|}{ Stagnic Technosol (Clayic) - profile 2} \\
\hline $\mathrm{C} 1$ & $0-5$ & 4.1 & 3.07 & 0.076 & 0.1016 & 40 & 30 \\
\hline $\mathrm{C} 2$ & $5-20$ & 4.1 & 2.11 & 0.054 & 0.7208 & 39 & 3 \\
\hline C3 & $20-40$ & 4.0 & 2.24 & 0.055 & 0.0508 & 41 & 44 \\
\hline $\mathrm{Cg} 1$ & $40-70$ & 3.4 & 0.63 & 0.023 & 0.1112 & 27 & 6 \\
\hline $\mathrm{Cg} 2$ & $70-100$ & 3.8 & 0.31 & 0.011 & 0.1167 & 28 & 3 \\
\hline Average & & 3.85 & 1.67 & 0.044 & 0.2202 & 38 & 8 \\
\hline \multicolumn{8}{|c|}{ Endogleyic Luvisol (Siltic, Chromic) } \\
\hline $\mathrm{Ah}$ & $0-5$ & 5.4 & 2.82 & 0.300 & 0.0481 & 9 & 59 \\
\hline
\end{tabular}




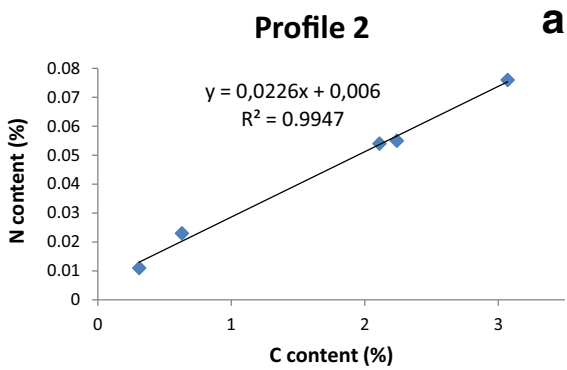

a

Profile 2

b

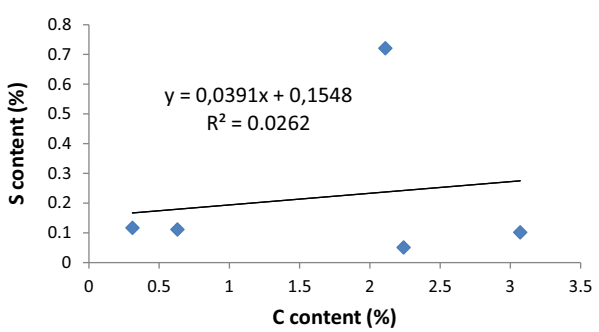

Fig. 4 Relationships between $\mathrm{C}$ and $\mathrm{N}$ (a) and $\mathrm{C}$ and $\mathrm{S}$ (b) in profile 2

sulfates up to $70 \%$ of the total S content. Hence, sulfates could affect the rate of simultaneous transformation of organic and inorganic pools resulting in decoupling of $\mathrm{C}$ and $\mathrm{S}$ cycles (Delgado-Baquerizo et al. 2013).

Variations of C:N values in depth of Technosols (Fig. 5a) generally reflect the heterogeneous deposition of layers with different carbon and nitrogen contents. Still, a trend of the gradual increase of $\mathrm{C}: \mathrm{N}$ values along depth of profile 1 should be marked. The trend describes negligible humus formation and low nitrogen proceeds (fixation) in older Technosols and clearly differentiates $\mathrm{A}$ and $\mathrm{C}$ horizons.

The narrowing ratio in depth of young soils could not be assigned to pedogenesis or organic matter morphogenesis occurring in natural soils. Coal fragments represent the major pool of carbon and may provoke the established characterization. They contain little nitrogen $(0.26 \%)$ bringing on extremely high value of C:N ratio (156) and excessive level of sulfur resulting in a very low $\mathrm{C}: \mathrm{S}$ value $(0.61)$.

Sulfur content in young soils remarkably exceeds (4 times) the amount found in natural soils /Endogleyic Luvisols (Siltic, Chromic)/ and sulfur clark concentration (480 mg/kg), and could add a chalcophile nature of soil environment (in the meaning of chalcophile elements prevalence). Still, the presence of both pyrite and coal fragments already modifies the geochemical features of young soils.

Values of $\mathrm{C}: \mathrm{S}$ ratio in all studied soils are low and reflect the local sulfur and carbon geochemistry and cycle patterns (Table 1, Fig. 5b). Usually, the values of C:S in soil organic horizons vary from 80 to 200 (Barber 1988) where S content is low due to the specifics of S cycle pattern which is briefly summarized by Peck (1993): "in most soils and natural environments, there is a continuous flux of sulphur through the biological sulphur cycle

a
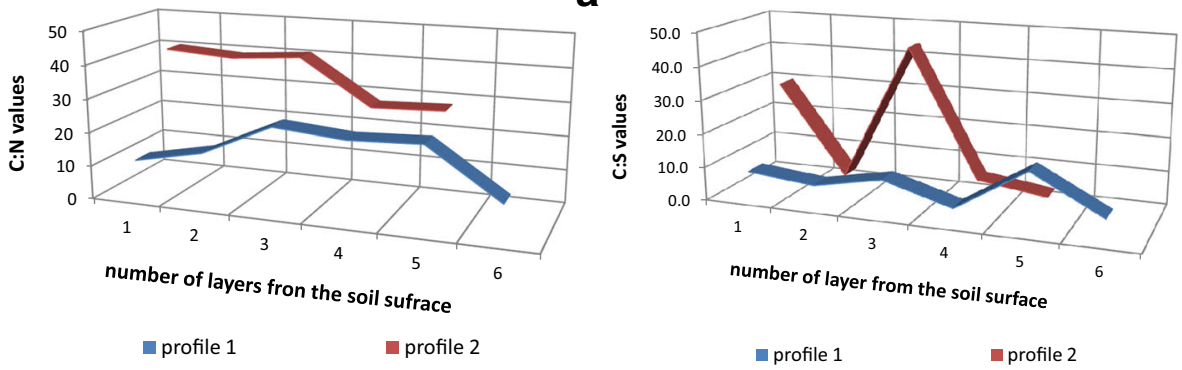

Fig. 5 Variations of C:N values (a) and C:S values (b) with depth of Technosols 
without the accumulation of intermediates or significant changes in the concentrations of sulfates and sulfides. This situation can then be regarded as an uninterrupted or continuous sulfur cycle".

\subsection{Soil Microbiota and Nutrients Fluxes}

Edaphological study help to reveal the leading processes and further development of pyrite containing Technosols. Microbiological studies complement the knowledge of biochemical processes controlling the fate of studied elements and are focused on the following microorganism colonies (Table 2):

- Oligotrophic bacteria-they mineralize mainly carbon-containing substances such as hydrocarbons and monosaccharides;

- Amonifying bacteria-they mineralize readily available nitrogen containing organic substances, such as free amino acids;

- Bacteria growing on mineral nitrogen-they transform mineral forms of nitrogen in organic compounds; actinomycetes - they decompose the more resistant organic substance and pigmented soil humus.

- Oligonitrophylic bacteria-they actively develop in an environment containing high levels of nitrogen and carbon and can fix the atmospheric nitrogen.

- Fungi -they are important decomposers in the soil food web. They convert hard-to-digest organic material into available forms.

Data in Table 2 shows that microorganisms delivering atmospheric nitrogen (Oligonitrophylic bacteria) prevail over those that transform organic compounds occurring in soils. Rapid growth of Oligonitrophylous indicates that carbon accumulates in the form of various readily available soil compounds in transformation of which ammonifyers and Bacteria assimilating mineral $N$ took part. A slight growth and low population density are typical of Oligotrophs but obviously the acidic $\mathrm{pH}$ injures their functionality and retards the mineralization rate of organic compounds in profile 2 . Actinomycetes colonies usually grow slowly and also are sensitive to acidity (optimum $\mathrm{pH}$ ranges from 6.5 to 8.0 ) and waterlogged soil conditions. Fungi predominate in vegetated soils although acidic $\mathrm{pH}$ (profile 2) also facilitates the growth of fungi genera. Oligonitrophylous and Oligotrophs are dominant in unvegetated soils which offer poor nutritious environment. Regardless of some impressive numbers, the microbial activity of Technosols is fainter than that of natural soils. Therefore, the biomass carbon is 3 to 12 times less in comparison with that in natural soils.

Table 2 The microbial abundance, activity and enumeration in studied soils

\begin{tabular}{|c|c|c|c|c|c|c|c|c|}
\hline \multirow[t]{3}{*}{ Objects } & \multirow{3}{*}{$\begin{array}{l}\text { Bioactivity } \\
\left(\mathrm{mg} \mathrm{CO}_{2} / 100 \mathrm{~g}\right)\end{array}$} & \multirow{3}{*}{$\begin{array}{l}\text { Biomass carbon } \\
(\mathrm{mg} / 100 \mathrm{~g})\end{array}$} & \multicolumn{5}{|l|}{ Million/g } & \multirow{3}{*}{$\begin{array}{l}\text { Thous. } \mathrm{g}^{-1} \\
\text { fungi }\end{array}$} \\
\hline & & & \multirow[t]{2}{*}{$\begin{array}{l}\text { Amoni-fying } \\
\text { bacteria }\end{array}$} & \multirow[t]{2}{*}{ Oligo-trophs } & \multirow[t]{2}{*}{ Oligoni-trophyls } & \multicolumn{2}{|c|}{$\begin{array}{l}\text { assimilating } \\
\text { mineral N }\end{array}$} & \\
\hline & & & & & & bacteria & $\begin{array}{l}\text { Actino- } \\
\text { micetes }\end{array}$ & \\
\hline Profile 1 & 2.919 & 8.951 & 8.633 & 5.697 & 116.667 & 28.133 & 6. 167 & 0.017 \\
\hline Profile 2 & 3.222 & 2.656 & 0.700 & 0.300 & 3.333 & 0.833 & 0.383 & 0.020 \\
\hline Luvisol & 9.814 & 24.296 & 6.100 & 1.307 & 52.333 & 5.067 & 6.433 & 0.187 \\
\hline
\end{tabular}


Table 3 Enumeration of the groups of thionic bacteria in studied soils (number of cells $/ \mathrm{ml}$ )

\begin{tabular}{llllllll}
\hline Objects & $\begin{array}{l}\text { Thioba-cillus } \\
\text { ferro-oxidans }\end{array}$ & $\begin{array}{l}\text { Lepto-spirillum } \\
\text { ferro-oxidans }\end{array}$ & $\begin{array}{l}\text { Thioba-cillus } \\
\text { thio-oxidans }\end{array}$ & $\begin{array}{l}\text { Thioba-cillus } \\
\text { thio-parus }\end{array}$ & $\begin{array}{l}\text { Thioba-cillus } \\
\text { like }\end{array}$ & $\begin{array}{l}\text { Hetero-trophic } \\
\text { acido-philes }\end{array}$ & $\begin{array}{l}\text { Colorless } \\
\text { sulphur-oxidizing } \\
\text { bacteria }\end{array}$ \\
\hline Profile 1 & $1.2 .10^{2}$ & - & $4.2 .10^{3}$ & $5.0 .10^{3}$ & - & $1.0 .10^{1}$ & $10^{1}$ \\
Profile 2 & $4.1 .10^{2}$ & $0.4 .10^{1}$ & $1.6 .10^{2}$ & $1.0 .10^{4}$ & $8.3 .10^{1}$ & $3.3 .10^{2}$ & $10^{1}$ \\
Max & $2.0 .10^{3}$ & $1.2 .10^{1}$ & $8.5 .10^{2}$ & $6.5 .10^{4}$ & $6.0 .10^{2}$ & $9.2 .10^{2}$ & $1.0 .10^{2}$ \\
$\min$ & 0.0 & 0.0 & $0.5 .10^{1}$ & 0.0 & 0.0 & 0.0 & 0.0 \\
Luvisol & - & - & $1.2 .10^{4}$ & $2.1 .10^{4}$ & - & $9.0 .10^{2}$ & $10^{1}$ \\
\hline
\end{tabular}

The carbon pool predominantly involves fresh and the newly formed organic matter although the stable form of organic carbon was also determined (paleocarbon, coal admixtures). The flux of available carbon is well distinguishable considering the number of Oligonitrophylic bacteria in studied Technosols. The increase of nitrogen pool and flux apparently is catalyzed by bacteria transforming the inorganic nitrogen into organic especially in the newly formed humus horizon of Gleyic Technosols (Siltic). Amonification also occurs in these soils and $\mathrm{C}: \mathrm{N}$ ratio reveal the fate of ammonia and further development of the nitrification process and $\mathrm{N}$ cycling. The sulfur pools and fluxes are more complicated and more versatile in soils and involve both organic and inorganic compounds. The microorganisms indigenous to acidic environments and known to be isolated from leached dumps and acid mine drainage water are listed in Table 3. Data show that the main oxidants of intermediate inorganic sulfur compounds (tetrathionate, thiosulfate, pyrite, elemental sulfur) Thiobacillus thiooxidans and Thiobacillus thioparus dominate in cinnamon soils followed by the group of Heterotrophic acidophiles which are also capable to oxidize the organic compounds. Colorless sulfur bacteria, Thiobacillus like and typical pyrite oxidants Thiobacillus ferrooxidans and Leptospirillum ferrooxidans joined to the oxidation of sulfides in technogenic soils. We should also admit that thionic bacteria are conditionally profiled and Thiobacillus thiooxidans also attack pyrite (Bacelar-Nicolau and Johnson Barrie 1999).

Data in Table 3 prove that microbial processes are pivotal for sulfur renewal and cycling in young Technosols. Sulfur inorganic intermediate compounds are continuously oxidizing and repeatedly transforming from pyrite and sulfides, the elemental sulfur and non-reduced compounds to sulphate and organic forms. In addition the acidic environment inhibits the growth of germs transforming carbon and nitrogen organic compounds.

Soil microorganisms which accomplish the intensive fixation of atmospheric nitrogen and transform readily available nitrogen containing organic substances prevail in Gleyic Technosols (Siltic) distinguished for lower pyrite content and neutral $\mathrm{pH}$.

\section{Conclusion}

Controlling the success of plant germination and cover formation, Technosols geochemistry significantly influences the accumulation and chemical transformation of carbon, nitrogen and sulfur.

Carbon and nitrogen geochemical pools are interlinked by organic matter in Gleyic Technosols (Siltic). Soil microbiota predominantly manage nitrogen organic and inorganic fluxes and presumably are the main reason for low saturation of organic matter with nitrogen $(\mathrm{C}: \mathrm{N}=11)$. Amonification provides further $\mathrm{N}$ cycling. In young Technosols/Stagnic Technosols (Clayic)/prevail the pools of coal carbon and the scarce flux of nitrogen. The average value of $\mathrm{C}: \mathrm{N}$ is 38 but still the strong correlation between these elements exists. Pyrite 
is the main source of sulfur providing predominance of inorganic pools and fluxes. It conceals the natural interlink beteewn carbon and sulfur organic pools resulting in very low values of $\mathrm{C}: \mathrm{S}$ (average value of 7.5). Microorganisms responsible for the oxidative turnover of inorganic sulfur compounds prevail and further sustain the acidic $\mathrm{pH}$ in young soil solum.

Acknowledgement The present publication has been prepered with the suuport of the project BG051PO0013.3.06-0042 "Program for Improvement of the Interdisciplinary Training and Raising the Qualification of Young Scienticts in the Field of Soil Science and Ecology" which is financed by the Operational Program "Human Resource Development" and the European Social Fund.

\section{References}

Anderson I, Domsch A (1978) A physiological method for the quantitative measurment of microbial biomass in soil. Soil Biol Biochem 10:215-221

Bacelar-Nicolau P, Johnson Barrie D (1999) Leaching of pyrite by acidophilic heterotrophic iron-oxidizing bacteria in pure and mixed cultures. Appl Environ Microbiol 65(2):585-590, PMCID: PMC91065

Banov M, Tsolova V, Totev L, Ivanov P (2013) A handbook of studying and reclamation of technogenic and disturbed soils, technical liquidation and conservation of mine objects. Ambrossia NT LTD, Sofia, p 98

Barber SA (1988) Biological availability of nutrients in soils. Agropromizdat, Moscow, p 375

Benvenuti M, Mascaro I, Corsini F, Lattanzi P, Parrini P, Tanelli G (1997) Mine waste dumps and heavy metal pollution in abandoned mining district of Boccheggiano (Southern Tuscany, Italy). Environ Geol 30(3/4): 238-243

BSS ISO 10381-2:2005. Soil quality - sampling - part 2: guidance on sampling techniques

BSS ISO 10381-4:2005. Soil quality - sampling - part 4: guidance on the procedure for investigation of natural, near-natural and cultivated sites

BSS ISO 11048:2002. Soil quality - determination of water-soluble and acid-soluble sulfate

BSS ISO 11261:2002. Soil quality - determination of total nitrogen - modified Kjeldahl method

BSS ISO 11464:2012. Soil quality - pretreatment of samples for physico-chemical analysis

Ciolkosz EJ, Cronce RC, Cunningham RL, Petersen GW (1985) Characteristics, genesis, and classification of Pennsylvania mine soils. Soil Sci 139:232-238

Delgado-Baquerizo M, Maestre Fernando T, Antonio G, Bowker Matthew A, Wallenstein Matthew D, Luis QJ, Victoria O, Beatriz G et al (2013) Decoupling of soil nutrient cycles as a function of aridity in global drylands. Nature 502:672-676. doi:10.1038/nature12670

Donggan G, Zhongke B, Tieliang S, Hongbo S, Wen Q (2011) Impacts of coal mining on the aboveground vegetation and soil quality: a case study of Qinxin coal mine in Shanxi Province, China. Clean Soil Air Water 39(3):219-225. doi:10.1002/clen.201000236

Duchaufour P (1970) Bases of soil science. Soil evolution. Progress, Moscow, 591 pp

Fanning DS, Burch (1997) Chapter 32. In: reclamation of drastically disturbed lands. In: Barnhisel RI, Daniels WL, Darmody RG (eds) Agronomy series No. 41. American soc. Agronomy, Madison

Fanning DS, Fanning MCB (1989) Soil morphology, genesis, and classification. John Wiley and Sons, New York, p 395

FAO (2006) Guidelines for soil description. Fourth Edition. Rome, $97 \mathrm{p}$

Ghose MK (2005) Soil conservation for rehabilitation and revegetation of mine-degraded land. TERI Inf Dig Energy Environ 4(2):137-150

Groudeva VI, Ivanova IA, Groudev SN, Uzunov GC (1993) Enhanced oil recovery by stimulating the activity of the indigenous microflora of soil reservoirs. In: Biohydrometall. Technol., Torma AE, Apel ML and Brieley CL (Eds.), II TMS Minerals, Metals and Materials Society, Warrendale, PA, 349-356

Hegler F, Posth N, Jiang J, Kappler A (2008) Physiology of phototrophic iron(II)-oxidizing bacteria: implications for modern and ancient environments. FEMS Microbiol Ecol 66(2):250-260

IUSS, Working Group WRB (2006) World reference base for soil resources, 2nd edition. World Soil Res reports No. 103. FAO, Rome

Johnson CD, Skousen JG (1995) Mine soil properties of 15 abandoned mine land sites in West Virginia. J Environ Qual 24:635-643

Karavaiko GI, Rossi G, Agate AD, Groudev SN, Avakyan ZA (1988) Biotechnology of metals, manual center for international projects. GKNT, Moscow

Marinkina V (1999) Studying and possibilities for reclamation of sulfide containing materials disclosed in the open cast mining. Ph.D. Thesis. Agricultural academy, N. Poushkarov Inst Soil Sci Agro Ecol, Sofia, 231pp 
Marinkina V, Banov M (2001) Biological reclamation of spoils containing pyrite. In: proceedings of the Jubilee scientific session "80 years high agronomic education in Bulgaria". Agric Univ Plovdiv XLVI(2):67-72

McCloy DV and Sencindiver JC (1991) Acid mine soil properties relating to sulfuricization. In: Agronomy Abstracts. ASA, Madison, WI. Appendix 2, p. 4

Ministry of environment and water of bulgaria, executive environment agency (MEW, ExEA) (2014) The national report of the environment state and protection in Bulgaria during the 2012. Sofia. 2014, $260 \mathrm{p}$

Orlov DS (1995) Humic substances of soils and general theory of Humification. A. A. Balkema, Netherlands, $p$ $323 \mathrm{pp}$

Peck HDJ (1993) Bioenergetics strategies of the sulfate-reducing bacteria. In: Singleton Jr (ed) The sulfatereducing bacteria: contemporary perspectives. Springer, New York, pp 41-76

Sencindiver JC, Ammons JT (2000) Mine soil genesis and classification. Chapter 23. In: Barnhisel RI, Daniels WL, Darmody RG (eds) Reclamation of drastically disturbed lands. Agronomy Series No. 41. American Soc. Agronomy, Madison

Sheoran AS, Sheoran V (2006) Heavy metal removal mechanism of acid mine drainage in wetlands: a critical review. Miner Eng 19(2):105-116

Sheoran AS, Sheoran V, Poonia P (2008) Rehabilitation of mine degraded land by metallophytes. Min Eng J 10(3):11-16

Sheoran V, Sheoran AS and Poonia P (2010) Soil reclamation of abandoned mine land by revegetation: a review, Int J Soil, Sediment Water: Vol. 3: Iss. 2, Article 13. Available at: http://scholarworks.umass.edu/intljssw/ vol3/iss $2 / 13$

Singh RN, Grube WE, Smith RM Jr, Keefer RF (1982) Relation of pyritic sandstone weathering to soil and minesoil properties. In: acid sulfate weathering. Soil Science Society of America, Madison, pp 193-208

Slattery WJ and Surapeneni A (2002) Can organic fertilizer enhance carbon sequestration in soils? On: CD, 17 WCSS, 14-21 August 2002, Thailand, Symposium 10, paper 1705

Thorsten C (2013) Some chemistry of acid mine drainage. CR scientific LLC. Web $<$ http://www.crscientific.com/ amd.html>

Tsolova V, Kolchakov V, Hristova M (2011) Organic carbon pools in reclaimed Technosols from Chukurovo mine region. Soil Sci Agro Chem Ecol 1-4:51-54

Tsolova V, Hristova M, Krasteva V, Kolchakov V (2012) Relative evaluation of technosols. III. Suitability for forage crops cultivation. Soil Sci Agro Chem Ecol XLVI(№ 1):42-50

USEPA (1978) Acid mine drainage and subsidence: effects on increased coal utilization. Environ Prot Technol Ser. ERA-600/2-78-068

Wong MH (2003) Ecological restoration of mine degraded soils, with emphasis on metal contaminated soils. Chemosphere 50:775-780

Yazawa Y, Ohmori H, Hirth J, Slattery B and Yamaguchi T (2002) Effect of soil humic substances on the sequestration of carbon in acid affected soils of South-Eastern Australia. On: CD, 17th WCSS, 14-21 August 2002, Thailand, Symposium 20, paper 944 